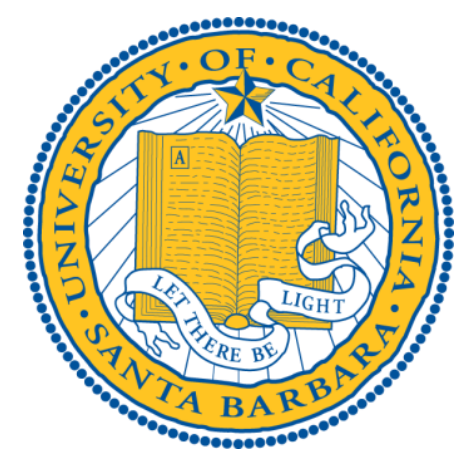

\title{
Phase Equilibria in the Calcia-Gadolinia-Silica System
}

\author{
David L. Poerschke* ${ }^{\dagger}$ and Carlos G. Levi* \\ *Materials Department, University of California, Santa Barbara, CA 93106-5050
}

\begin{abstract}
The phase equilibria in the $\mathrm{CaO}-\mathrm{Gd}_{2} \mathrm{O}_{3}-\mathrm{SiO}_{2}$ system were investigated by heat treating precursor-derived powders at $1400^{\circ} \mathrm{C}$ and $1600^{\circ} \mathrm{C}$, determining the resulting phase assemblages, and measuring the compositions of the liquid and solid solution phases. The stable ternary phases at $1400^{\circ} \mathrm{C}$ include silico-carnotite $\left(\mathrm{Ca}_{3} \mathrm{Gd}_{2} \mathrm{Si}_{3} \mathrm{O}_{12}\right), \mathrm{Ca} / \mathrm{Gd}$-cyclosilicate $\left(\mathrm{Ca}_{3} \mathrm{Gd}_{2} \mathrm{Si}_{6} \mathrm{O}_{26}\right)$, and the apatite solid solution field extending from $\mathrm{Gd}_{9.33}\left(\mathrm{SiO}_{4}\right)_{6} \mathrm{O}_{2}$ to $\mathrm{Ca}_{2.75} \mathrm{Gd}_{7.25}\left(\mathrm{SiO}_{4}\right)_{6} \mathrm{O}_{1.625}$. Of these, only apatite remains stable to $1600^{\circ} \mathrm{C}$. The high-temperature $\alpha$ - and $\alpha-\mathrm{Ca}_{2} \mathrm{SiO}_{4}$ polymorphs exhibit moderate $\mathrm{Gd}_{2} \mathrm{O}_{3}$ solubility. The results are compared to the equilibria for the related $\mathrm{CaO}-\mathrm{Y}_{2} \mathrm{O}_{3}-\mathrm{SiO}_{2}$ system. The implications for understanding the interaction between rare earth containing thermal barrier coatings (TBCs) and silicate deposits (CMAS) are discussed.

Keywords: ceramics, rare earth compounds, phase diagrams, silicates, apatite
\end{abstract}

Author to whom correspondence should be addressed: poerschke@engineering.ucsb.edu.

Manuscript submitted to Journal of Alloys and Compounds, September 2016

(C) 2016. This manuscript version is made available under the Elsevier user license http://www.elsevier.com/open-access/userlicense/1.0/ 


\section{INTRODUCTION}

Phases in the ternary $\mathrm{CaO}-\mathrm{GdO}_{1.5}{ }^{\mathrm{a}}-\mathrm{SiO}_{2}$ (CGS) system are of interest for their luminescent properties [1], as ionic conductors for solid oxide fuel cells [2,3], and as prospective thermoelectric materials [4]. The crystallization of CGS phases from multi-component oxide melts also plays an important role in mitigating thermal barrier coating (TBC) degradation caused by molten silicate deposits (CMAS) in modern turbine engines [5,6]. In this context, $\mathrm{GdO}_{1.5}$ (or other rare earth oxides, $\mathrm{REO}_{1.5}$ ) from the coating react with $\mathrm{CaO}$ and $\mathrm{SiO}_{2}$ in the deposit to rapidly precipitate an apatite phase, blocking open gaps in the coating structure and significantly slowing melt infiltration [5]. The dynamics of these reactions are determined by the solubility of the $\mathrm{REO}_{1.5}$ in the melt and the driving force to precipitate apatite relative to other reaction products. Information about the phase relationships and solid solution homogeneity ranges in the CGS system is needed for optimizing system performance in functional applications and for interpreting the reaction sequences that effectively mitigate CMAS degradation.

Although the properties and behavior of individual CGS phases have been studied, there has not been a comprehensive assessment of the system to identify all of the ternary phases and their equilibrium relationships. The current study, an experimental investigation of the ternary CGS phase equilibria at $1400^{\circ} \mathrm{C}$ and $1600^{\circ} \mathrm{C}$, addresses this need. The details of the solid-state equilibria at $1400^{\circ} \mathrm{C}$ are relevant to the design and processing of functional materials. Meanwhile, the experiments at $1600^{\circ} \mathrm{C}$ provide insight into the liquid-solid equilibria and the extent of the liquid field compared to related systems. These details are relevant to ongoing efforts to expand thermodynamic databases to include expected CMAS reaction products.

This study builds upon a recent investigation of the related $\mathrm{CaO}-\mathrm{YO}_{1.5}-\mathrm{SiO}_{2}(\mathrm{CYS})$ system [7]. Although some similarities are observed, the exchange of $\mathrm{Y}^{3+}$ for $\mathrm{Gd}^{3+}$ (with a $\sim 4 \%$ increase in ionic radius [8]) impacts the stability and homogeneity ranges of the phases. This investigation therefore focused on elucidating the differences between the two systems. The discussion of the results highlights the findings that are unique to the CGS system.

a Molar concentrations of single cation formula units (i.e. $\mathrm{GdO}_{1.5}$ rather than $\mathrm{Gd}_{2} \mathrm{O}_{3}$ ) are used to more readily relate stoichiometric changes to the underlying crystal chemistry. Where appropriate, the compact notation $\mathrm{C}=$ $\mathrm{CaO}, \mathrm{S}=\mathrm{SiO}_{2}$, and $\mathrm{G}=\mathrm{GdO}_{1.5}$ is used (e.g., $\mathrm{C}_{3} \mathrm{G}_{2} \mathrm{~S}_{3}=\mathrm{Ca}_{3} \mathrm{Gd}_{2} \mathrm{Si}_{3} \mathrm{O}_{9}$ ). 


\section{BACKGROUND ON PHASE EQUILIBRIA}

The known CGS phases are listed in Table 1. The current understanding of the binary and ternary phase equilibria are provided in the following sections. Additional background about the structures and crystal chemistry of the ternary phases is provided in the earlier article focused on the CYS system [7].

\subsection{End Members and Binary Subsystems}

$\mathrm{CaO}$ is stable with a single polymorph until it melts at $2613^{\circ} \mathrm{C}$. There are five $\mathrm{GdO}_{1.5}$ polymorphs. The transformations B- $\leftrightarrow \mathrm{A}-\leftrightarrow \mathrm{H}-\leftrightarrow \mathrm{X}^{-\mathrm{GdO}_{1.5}}$ occur at $2170^{\circ} \mathrm{C}, 2208^{\circ} \mathrm{C}$, and $2360^{\circ} \mathrm{C}$, respectively; the temperature of the $\mathrm{C}-\leftrightarrow \mathrm{B}^{-} \mathrm{GdO}_{1.5}$ transition around $1200^{\circ} \mathrm{C}$ is less well defined due to slow reaction kinetics [9]. The equilibrium phases for $\mathrm{SiO}_{2}$ include $\alpha$ - and $\beta$ quartz, HP-tridymite, and $\beta$-cristobalite with transitions at $574^{\circ} \mathrm{C}, 867^{\circ} \mathrm{C}$, and $1470^{\circ} \mathrm{C}$ before melting at $1723^{\circ} \mathrm{C}$ [10]. However, $\mathrm{SiO}_{2}$ exhibits a variety of metastable polymorphs [11] and rather than following the equilibrium sequence amorphous $\mathrm{SiO}_{2}$ typically crystallizes as $\beta$ cristobalite and transforms to $\alpha$-cristobalite upon cooling.

There are four ternary $\mathrm{CaO}-\mathrm{SiO}_{2}$ phases: $\mathrm{CaSiO}_{3}, \mathrm{Ca}_{3} \mathrm{Si}_{2} \mathrm{O}_{7}, \mathrm{Ca}_{2} \mathrm{SiO}_{4}$, and $\mathrm{Ca}_{3} \mathrm{SiO}_{5}$ [12]. All four are stable at $1400^{\circ} \mathrm{C}$; at this temperature $\mathrm{CS}$ and $\mathrm{C}_{2} \mathrm{~S}$ exhibit the pseudo-wollastanite (C2/c) and $\alpha^{\prime}$ (Pnma) structures, respectively. At $1600^{\circ} \mathrm{C}$ the $\alpha-\mathrm{C}_{2} \mathrm{~S}\left(\mathrm{P} 6_{3} / \mathrm{mmc}\right)$ structure is stable while CS and $\mathrm{C}_{3} \mathrm{~S}_{2}$, which melt congruently at $1544^{\circ} \mathrm{C}$ and $1464^{\circ} \mathrm{C}$, respectively, should not be observed. In the related CYS system the $\alpha$ - and $\alpha-\mathrm{C}_{2} \mathrm{~S}$ structures have significant ( $\left.10 \mathrm{~mol} \%\right)$ $\mathrm{YO}_{1.5}$ solubility $[7,13]$ but $\mathrm{YO}_{1.5}$ is effectively insoluble in the lower-temperature larnite and $\gamma$ $\mathrm{C}_{2} \mathrm{~S}$ polymorphs. Similar behavior is expected for the CGS system. There is a liquid miscibility gap above $\sim 1700^{\circ} \mathrm{C}$ in the range $72 \mathrm{~mol} \%$ to $98 \mathrm{~mol} \% \mathrm{SiO}_{2}[14,15]$.

Three binary $\mathrm{GdO}_{1.5}-\mathrm{SiO}_{2}$ phases are reported [16]. The disilicate $\left(\mathrm{Gd}_{2} \mathrm{Si}_{2} \mathrm{O}_{7}, \alpha \rightarrow \delta\right.$ at $\sim 1450^{\circ} \mathrm{C}$ [17] $)$ and the monosilicate $\left(\mathrm{Gd}_{2} \mathrm{SiO}_{5}\right)$ are line compounds. The third binary phase, $\mathrm{Gd}_{9.33}\left(\mathrm{SiO}_{4}\right)_{6} \mathrm{O}_{2}$, is the $\mathrm{CaO}$-deficient end member of the solid solution range for the apatite phase based on the $\mathrm{Ca}_{2} \mathrm{Gd}_{8}\left(\mathrm{SiO}_{4}\right)_{6} \mathrm{O}_{2}$ stoichiometry. Additional details about the structure and stability range for apatite are provided in Section 2.2. A liquid miscibility gap is reported above $\sim 1700^{\circ} \mathrm{C}$ in the $\mathrm{SiO}_{2}$-rich side of the $\mathrm{GdO}_{1.5}-\mathrm{SiO}_{2}$ system [16]. 
There is a single binary compound, $\mathrm{CaGd}_{4} \mathrm{O}_{7}$, in the $\mathrm{CaO}-\mathrm{GdO}_{1.5}$ system [18]. Although the structure has not been extensively characterized, this phase is reportedly similar to B-type $\mathrm{GdO}_{1.5}$ [9]. It is hypothesized that $\mathrm{CG}_{4}$ arises as a distinct phase due to the ordering of the anion vacancies introduced as $\mathrm{CaO}$ dissolves into $\mathrm{B}-\mathrm{GdO}_{1.5} \cdot \mathrm{CG}_{4}$ melts around $2200^{\circ} \mathrm{C}$ but the low temperature stability limit is unclear, possibly due to difficulties distinguishing the phase from B$\mathrm{GdO}_{1.5}$. One report indicates that $\mathrm{CG}_{4}$ is stable to temperatures as low as $1500^{\circ} \mathrm{C}$ [19] while other studies concluded that $\mathrm{CG}_{4}$ decomposes to a mixture of $\mathrm{CaO}$ and $\mathrm{GdO}_{1.5}$ below $1600^{\circ} \mathrm{C}$ [20], $1650^{\circ} \mathrm{C}$ [18], or $1700^{\circ} \mathrm{C}$ [21]. There are also conflicting reports about the solubility of $\mathrm{GdO}_{1.5}$ and $\mathrm{CaO}$ in one another. Barry et al. found that $\mathrm{CaO}$ dissolves up to $11 \mathrm{~mol} \% \mathrm{GdO}_{1.5}$ in the range $1600^{\circ} \mathrm{C}$ to $2100^{\circ} \mathrm{C}$ and that $\mathrm{CaO}$ is virtually insoluble in $\mathrm{B}$-type $\mathrm{GdO}_{1.5}$ at $1850^{\circ} \mathrm{C}$. Conversely, Gulamova et al. found negligible $\mathrm{GdO}_{1.5}$ solubility in $\mathrm{CaO}$ but report that $\mathrm{GdO}_{1.5}$ dissolves 6 $\mathrm{mol} \% \mathrm{CaO}$ at $1700^{\circ} \mathrm{C}$ and $3.5 \mathrm{~mol} \% \mathrm{CaO}$ at $1400^{\circ} \mathrm{C}$ [21].

\subsection{Ternary Phases}

Two ternary CGS phases have been reported. These are the silicocarnotite phase, $\mathrm{Ca}_{3} \mathrm{Gd}_{2}\left(\mathrm{SiO}_{4}\right)_{3}$, [1] and the apatite phase, nominally $\mathrm{Ca}_{2} \mathrm{Gd}_{8}\left(\mathrm{SiO}_{4}\right)_{6} \mathrm{O}_{2}$ [22]. Based on the equilibria in other $\mathrm{CaO}-\mathrm{REO}_{1.5}-\mathrm{SiO}_{2}$ systems, the ternary system may also include $\mathrm{Ca}_{3} \mathrm{Gd}_{2}\left(\mathrm{Si}_{3} \mathrm{O}_{9}\right)_{2}$, a monoclinic cyclosilicate structurally similar to pseudo-wollastonite [23], and an orthorhombic cuspidine-type phase [7,24], $\mathrm{Ca}_{2} \mathrm{Gd}_{2} \mathrm{Si}_{2} \mathrm{O}_{9}$, which would be related to the monoclinic rare earth aluminates (e.g. $\mathrm{Gd}_{4} \mathrm{Al}_{2} \mathrm{O}_{9}$ ). Experience in the $\mathrm{CaO}-\mathrm{YO}_{1.5}-\mathrm{SiO}_{2}$ system [7] indicates that $\mathrm{C}_{3} \mathrm{G}_{2} \mathrm{~S}_{3}$ and $\mathrm{C}_{3} \mathrm{G}_{2} \mathrm{~S}_{6}$ should be line compounds while in apatite and cuspidine can exhibit solid solution homogeneity ranges enabled by ionic substitutions.

The apatite structure is described by the general formula $\mathrm{M}_{4}^{\mathrm{I}} \mathrm{M}_{6}{ }_{6}^{\mathrm{II}}\left(\mathrm{SiO}_{4}\right)_{6} \mathrm{X}_{2}$. Using this nomenclature, $\mathrm{M}^{\mathrm{I}}$ and $\mathrm{M}^{\mathrm{II}}$ correspond to columns of cation sites along the c-axis of the hexagonal unit cell. The $\mathrm{M}^{\mathrm{I}}$ and $\mathrm{M}^{\mathrm{II}}$ sites are coordinated by 9 and 7 oxygen atoms, respectively. The $\mathrm{X}$ site, located within a ring of $\mathrm{M}^{\mathrm{II}}$ columns, hosts anions not covalently bound in the Si tetrahedra. In the CGS system the $\mathrm{X}$ sites are occupied by oxygen, $\mathrm{Gd}^{3+}$ occupies the $\mathrm{M}^{\mathrm{II}}$ site, and the $\mathrm{M}^{\mathrm{I}}$ site can be occupied by a combination of $\mathrm{Ca}^{2+}$ and $\mathrm{Gd}^{3+}$. Without introducing vacancies or interstitials, charge balance is achieved for the case where $\mathrm{M}^{\mathrm{I}}$ contains two $\mathrm{Ca}^{2+}$ and two $\mathrm{Gd}^{3+}$, $\left(\mathrm{Ca}_{2} \mathrm{Gd}_{2}\right) \mathrm{Gd}_{6}\left(\mathrm{SiO}_{4}\right)_{6} \mathrm{O}_{2}$ (or, more simply, $\left.\mathrm{Ca}_{2} \mathrm{Gd}_{8} \mathrm{Si}_{6} \mathrm{O}_{26}\right)$ [4]. $\mathrm{CaO}$ and $\mathrm{GdO}_{1.5}$ may be substituted for one another according to $\mathrm{Gd}_{8+\mathrm{x}} \mathrm{Ca}_{2+\mathrm{y}}\left(\mathrm{SiO}_{4}\right)_{6} \mathrm{O}_{2+3 \times / 2+\mathrm{y}}$. The apatite composition space enabled 
by these substitutions is plotted in Figure 1(a). Increasing the Ca:Gd ratio $(x=-y, x<0)$ introduces oxygen vacancies on the $\mathrm{X}$ sites to maintain charge balance. In the $\mathrm{CaO}$-rich direction the substitutions are limited to the case where every $\mathrm{M}^{\mathrm{I}}$ site is occupied by $\mathrm{Ca}$ (i.e. $\left.\mathrm{Ca}_{4} \mathrm{Gd}_{6}\left(\mathrm{SiO}_{4}\right)_{6} \mathrm{O}, x=-2\right)$. Alternatively, increasing the relative $\mathrm{Gd}$ content $(x>0)$ requires either cation vacancies $(x=-2 y / 3)$ or oxygen interstitials $(x=-y)$. The terminal $\mathrm{CaO}$-free compositions could therefore be in the range from $\mathrm{Gd}_{9.33}\left(\mathrm{SiO}_{4}\right)_{6} \mathrm{O}_{2}$ to $\mathrm{Gd}_{10}\left(\mathrm{SiO}_{4}\right)_{6} \mathrm{O}_{3}$.

Prior studies have examined the apatite stability over this notional range. The $\mathrm{Gd}_{9.33}\left(\mathrm{SiO}_{4}\right)_{6} \mathrm{O}_{2}$ stoichiometry is generally accepted as stable [3,4,25]. Nakayama et al. [2] studied the properties of material identified as $\mathrm{Gd}_{10}\left(\mathrm{SiO}_{4}\right)_{6} \mathrm{O}_{3}$, although they note the presence of $\mathrm{G}_{2} \mathrm{~S}$ impurities and don't provide clear evidence differentiating their predominant phase from $\mathrm{Gd}_{9.33}\left(\mathrm{SiO}_{4}\right)_{6} \mathrm{O}_{2}$. Slater et al. later reported that $\mathrm{Gd}_{10}\left(\mathrm{SiO}_{4}\right)_{6} \mathrm{O}_{3}$ is not stable but found that the ionic conductivity increases for compositions on the $\mathrm{GdO}_{1.5}$-rich side of $\mathrm{Gd}_{9.33}\left(\mathrm{SiO}_{4}\right)_{6} \mathrm{O}_{2}$ [3] . Based on these results they conclude that oxygen interstitials could be incorporated up to $\mathrm{Gd}_{9.67}\left(\mathrm{SiO}_{4}\right)_{6} \mathrm{O}_{2.5}$. Qu et al. also found that $\mathrm{Gd}_{10}\left(\mathrm{SiO}_{4}\right)_{6} \mathrm{O}_{3}$ is not stable but conclude that the CGS apatite is stable over the full range of compositions permitted by vacancy incorporation (i.e. $\mathrm{Ca}_{4} \mathrm{Gd}_{6}\left(\mathrm{SiO}_{4}\right)_{6} \mathrm{O}$ to $\left.\mathrm{Gd}_{9.33}\left(\mathrm{SiO}_{4}\right)_{6} \mathrm{O}_{2}\right)[4]$.

\section{EXPERIMENTAL METHODS}

Powders corresponding to the compositions listed in Table 2 were synthesized from ethanol-based solutions of gadolinium nitrate (99.9\%, Alfa Aesar, Ward Hill, MA), calcium nitrate (99.9\%, Fisher Scientific, Pittsburgh, PA), and tetraethyl orthosilicate (TEOS, reagent grade, Fisher Sci.) via dropwise addition into an aqueous ammonium hydroxide/carbonate solution. The resulting Gd- and Si-hydroxide and $\mathrm{Ca}$-carbonate precipitates were washed in ethanol and pyrolyzed in air at $1000^{\circ} \mathrm{C}$.

The oxide powders were pressed into $6 \mathrm{~mm}$ diameter, $1.5 \mathrm{~mm}$ thick pellets and wrapped in platinum foil prior to equilibration in air. Specimens in sub-solidus phase fields were annealed in zirconia boats (machined from FBD, Zircar Zirconia, Florida, NY) in a zirconia furnace tube (McDanel Advanced Ceramics, Beaver Falls, PA) for $200 \mathrm{~h}$ at $1400^{\circ} \mathrm{C}$ or $100 \mathrm{~h}$ at $1600^{\circ} \mathrm{C}$. Zirconia hardware was used to prevent contamination by alumina. The longer time at $1400^{\circ} \mathrm{C}$ helped grow the grains to a sufficient size for composition analysis. The specimens were polished using diamond lapping films, thermally etched at the equilibration temperature for $1 \mathrm{~h}$, 
and quenched into air. Compositions forming a liquid phase at $1600^{\circ} \mathrm{C}$ were suspended from platinum wire in a box furnace (to facilitate fast extraction), held for $5 \mathrm{~h}$, and water quenched prior to mounting in epoxy, cross sectioning, and polishing. An alcohol/glycol lubricant was used for specimens containing water-sensitive phases (e.g., $\mathrm{CaO}$ ).

The equilibrated specimens were characterized using a combination of $\mathrm{x}$-ray diffraction (XRD, Panalytical Empyrean, Westborough, MA), scanning electron microscopy (SEM, XL30 Sirion FEG, FEI, Hillsboro, OR), and transmission electron microscopy (TEM, Technai G2 Sphera, FEI). When grains were sufficiently large, phase compositions were measured by wavelength dispersive spectroscopy (EPMA, SX-100, Cameca, Madison, WI). The compositions of fine-grained phases were measured using energy dispersive spectroscopy in the TEM (TEMEDS, Oxford Inca, Concord, MA). Multiple grains of each phase were measured; typical standard deviations were less than $1 \mathrm{~mol} \%$. Internal standards were used to assess the accuracy of these measurements. The errors in the EPMA and EDS data were generally of order $1 \%$ and $5 \%$ of the measured values, respectively.

\section{RESULTS AND DISCUSSION}

\subsection{General Phase Relationships at $1400^{\circ} \mathrm{C}$ and $1600^{\circ} \mathrm{C}$}

The experimentally determined equilibrium phase assemblages and compositions are reported in Table 2 and Table 3, respectively. This data is plotted as two- and three-phase fields in Figure $2(\mathrm{a}, \mathrm{b})$ and was used to construct the $1400^{\circ} \mathrm{C}$ and $1600^{\circ} \mathrm{C}$ isothermal sections in Figure 2 (c, d). At $1400^{\circ} \mathrm{C}_{3} \mathrm{G}_{2} \mathrm{~S}_{3}$ and $\mathrm{C}_{3} \mathrm{G}_{2} \mathrm{~S}_{6}$ were confirmed as stable phases; both phases melt between $1400^{\circ} \mathrm{C}$ and $1600^{\circ} \mathrm{C}$. Apatite was observed at $1400^{\circ} \mathrm{C}$ and $1600^{\circ} \mathrm{C}$. Cuspidine, hypothetically $\mathrm{C}_{2} \mathrm{G}_{2} \mathrm{~S}_{2}$ based on the equivalent $\mathrm{C}_{2} \mathrm{Y}_{2} \mathrm{~S}_{2}$, was not observed at either temperature. The small liquid field discovered at $1400^{\circ} \mathrm{C}$ expands considerably at $1600^{\circ} \mathrm{C}$ where it shares phase fields with $\mathrm{SiO}_{2}$, apatite, and $(\mathrm{Ca}, \mathrm{Gd})_{2} \mathrm{SiO}_{4}$. The details of the temperature-dependent shifts in phase stability and the solution homogeneity ranges are discussed in the following sections.

\subsection{Apatite Homogeneity Range}

Specimens with compositions located on both sides of $\mathrm{Gd}_{9.33}\left(\mathrm{SiO}_{4}\right)_{6} \mathrm{O}_{2}$ between $\mathrm{G}_{2} \mathrm{~S}_{2}$ and $\mathrm{G}_{2} \mathrm{~S}$ (ID 1 and 2, respectively) were used to confirm the width of the apatite field along the 
$\mathrm{GdO}_{1.5}-\mathrm{SiO}_{2}$ binary. The equilibrium microstructures at $1400^{\circ} \mathrm{C}$, not shown, and $1600^{\circ} \mathrm{C}$, Figure $1(b, c)$, contained apatite and either $\mathrm{G}_{2} \mathrm{~S}_{2}$ and $\mathrm{G}_{2} \mathrm{~S}$. The measured apatite compositions corresponding the $\mathrm{SiO}_{2}$-rich and $\mathrm{SiO}_{2}$-lean sides of the binary apatite field, plotted in Figure 1(a), are within $\sim 1 \mathrm{~mol} \%$ of one another and are centered near $\mathrm{Gd}_{9.33}\left(\mathrm{SiO}_{4}\right)_{6} \mathrm{O}_{2}$. This result confirms that apatite stoichiometries that would require oxygen interstitials are thermodynamically unfavorable.

The microstructures of specimens with the composition corresponding to $\mathrm{Ca}_{4} \mathrm{Gd}_{6}\left(\mathrm{SiO}_{4}\right)_{6} \mathrm{O}$ (ID 4, the $\mathrm{CaO}$-rich end of the notional apatite field) are shown in Figure 1(d-f). Neither specimen is single-phase apatite. At $1400^{\circ} \mathrm{C}$ the specimen contains apatite and a significant fraction of silico-carnotite $\left(\mathrm{C}_{3} \mathrm{G}_{2} \mathrm{~S}_{3}\right)$. At $1600^{\circ} \mathrm{C}$ apatite is in equilibrium with $(\mathrm{Ca}, \mathrm{Gd})_{2} \mathrm{SiO}_{4}$ and liquid. For both temperatures the measured terminal $\mathrm{GdO}_{1.5}$-lean apatite composition is approximately $\mathrm{Ca}_{2.75} \mathrm{Gd}_{7.25}\left(\mathrm{SiO}_{4}\right)_{6} \mathrm{O}_{1.625}(\sim 17 \mathrm{~mol} \% \mathrm{CaO}$, Figure 1(a)), located roughly midway between the defect-free $\mathrm{Ca}_{2} \mathrm{Gd}_{8}\left(\mathrm{SiO}_{4}\right)_{6} \mathrm{O}_{2}$ stoichiometry and $\mathrm{Ca}_{4} \mathrm{Gd}_{6}\left(\mathrm{SiO}_{4}\right)_{6} \mathrm{O}$. These observations indicate that the apatite stoichiometry $\mathrm{Ca}_{4} \mathrm{Gd}_{6}\left(\mathrm{SiO}_{4}\right)_{6} \mathrm{O}$ has a higher free energy than the multi-phase assemblages.

The present findings are consistent with reports that the $\mathrm{CaO}$ solubility is limited to $y<1$

for apatite containing either $\mathrm{NdO}_{1.5}$ (a larger cation) or $\mathrm{YO}_{1.5}$ (a smaller cation) [7,26] but contradict the report that $\mathrm{Ca}_{4} \mathrm{Gd}_{6}\left(\mathrm{SiO}_{4}\right)_{6} \mathrm{O}(y=2)$ and $\mathrm{Ca}_{3} \mathrm{Gd}_{7}\left(\mathrm{SiO}_{4}\right)_{6} \mathrm{O}_{1.5}(y=1)$ can be formed at $1600^{\circ} \mathrm{C}$ [4]. However, XRD, which was used for phase identification in the earlier CGS apatite work, would have limited sensitivity to detect the presence of glass and the partially decomposed $(\mathrm{Ca}, \mathrm{Gd})_{2} \mathrm{SiO}_{4}$ phase described in the next section. In fact, in the current investigation only reflections corresponding to the apatite phase were clearly discernable in the XRD spectrum for specimen ID 4 equilibrated at $1600^{\circ} \mathrm{C}$.

The remaining three-phase triangles defining the relationship between apatite and other phases (e.g., ID 7-10) all join the apatite phase near $\mathrm{Ca}_{2} \mathrm{Gd}_{8}\left(\mathrm{SiO}_{4}\right)_{6} \mathrm{O}_{2}$, suggesting a strong thermodynamic preference for the defect-free stoichiometry compared to those requiring vacancy formation.

\section{3 $\mathrm{GdO}_{1.5}$ Solubility in $\mathrm{Ca}_{2} \mathrm{SiO}_{4}$}

The $\alpha$ '- and $\alpha-\mathrm{C}_{2} \mathrm{~S}$ polymorphs appear to dissolve $\mathrm{GdO}_{1.5}$. However, conclusive analysis of the nature of these phases at high temperature is complicated by their tendency to transform to 
$\mathrm{GdO}_{1.5}$-free $\mathrm{C}_{2} \mathrm{~S}$ polymorphs upon cooling. After quenching, the initial $\mathrm{GdO}_{1.5}$-bearing $\mathrm{C}_{2} \mathrm{~S}$ grains in sub-solidus samples exhibit dark bands indicating the nucleation of a lower-temperature $\mathrm{C}_{2} \mathrm{~S}$ phase, Figure $3(\mathrm{a}, \mathrm{b}, \mathrm{d})$. In specimens containing a liquid phase the partial transformation upon quenching produces a mottled appearance, Figure 3 (c) and Figure 6 (e). The compositions reported in Table 3 and used to construct Figure 2 represent area measurements for these partially transformed regions. The maximum values indicate that $\alpha^{\prime}$-/ $\alpha$-can dissolve up to 8 mol\% and $14 \mathrm{~mol} \% \mathrm{GdO}_{1.5}$ at $1400^{\circ} \mathrm{C}$ and $1600^{\circ} \mathrm{C}$, respectively. The addition of $\mathrm{GdO}_{1.5}$ corresponds to a reduction in the $\mathrm{CaO}$ content, suggesting that $\mathrm{Gd}^{3+}$ substitutes for $\mathrm{Ca}^{2+}$ (i.e. $\left.(\mathrm{Ca}, \mathrm{Gd})_{2} \mathrm{SiO}_{4}\right)$. The measured $\mathrm{SiO}_{2}$ contents rise slightly at the higher $\mathrm{GdO}_{1.5}$ contents indicating that the formation of cation vacancies maintains charge balance in the structure.

\subsection{Equilibria in the CaO-GdO ${ }_{1.5}$ Binary}

Specimens 11 and 12 provide information about the $\mathrm{CaO}-\mathrm{GdO}_{1.5}$ binary equilibria. At $1400^{\circ} \mathrm{C}$ the XRD patterns for these samples, Figure 4, indicate that only $\mathrm{CaO}$ (ICSD 98-0075786 ) and $\mathrm{B}-\mathrm{GdO}_{1.5}$ (ICSD 98-063-6103) are stable along this binary. At $1400^{\circ} \mathrm{C} \mathrm{CaO}$ dissolves up to $3 \mathrm{~mol} \% \mathrm{GdO}_{1.5}$ while $\mathrm{B}-\mathrm{GdO}_{1.5}$ dissolves up to $7 \mathrm{~mol} \% \mathrm{CaO}$. The XRD spectra for the specimens annealed at $1600^{\circ} \mathrm{C}$ reveal the presence of $\mathrm{CaGd}_{4} \mathrm{O}_{7}$ (ICSD 98-002-0818) instead of $\mathrm{B}-\mathrm{GdO}_{1.5}$. However the composition measurements indicate that grains identified as $\mathrm{CG}_{4}$ were generally CaO-lean relative to the stoichiometric composition. This may indicate that $\mathrm{CG}_{4}$ exhibits a small homogeneity range extending toward the $\mathrm{GdO}_{1.5}$ corner.

\subsection{Homogeneity Ranges for Other Phases}

At $1400^{\circ} \mathrm{C}$ the composition measurements indicate that $\mathrm{C}_{3} \mathrm{G}_{2} \mathrm{~S}_{3}$ and $\mathrm{C}_{3} \mathrm{G}_{2} \mathrm{~S}_{6}$, Figure 5 (ac), are effectively line compounds with homogeneity ranges extending less than $1 \mathrm{~mol} \%$ from their nominal stoichiometries. The binary $\mathrm{G}_{2} \mathrm{~S}$ and $\mathrm{G}_{2} \mathrm{~S}_{2}$ phases exhibited less than $0.1 \mathrm{~mol} \%$ $\mathrm{CaO}$ solubility while $\mathrm{CS}$ dissolves less than $0.2 \mathrm{~mol} \% \mathrm{GdO}_{1.5} . \mathrm{C}_{3} \mathrm{~S}$ can dissolve up to $3 \mathrm{~mol} \%$ $\mathrm{GdO}_{1.5}$; like $\mathrm{C}_{2} \mathrm{~S}$, the $\mathrm{CaO}$ concentration in $\mathrm{C}_{3} \mathrm{~S}$ drops with increasing $\mathrm{GdO}_{1.5}$ content, consistent with the proposed $(\mathrm{C}, \mathrm{G})_{3} \mathrm{~S}$ formula.

\subsection{Liquid Field at $1600^{\circ} \mathrm{C}$}

The shape of the liquid field at $1600^{\circ}$ was assessed by measuring the glass compositions for the six specimens containing a liquid phase. The microstructures shown in Figure 6(a-d), IDs 
5, 6, 9, and 14, each contained single-phase liquid. The compositions at the $\mathrm{SiO}_{2}$-rich side of the liquid field, Figure 6(e,f) showed evidence of separation into $\mathrm{SiO}_{2}$-rich and -lean liquids. The microstructure for specimen ID 15, Figure 6(f), the phase separated liquid only appeared in regions away from the crystalline $\mathrm{SiO}_{2}$ grains. This observation suggests that the phase separation is either metastable at $1600^{\circ} \mathrm{C}$ or that it occurs upon cooling. Therefore, the average composition of the two phase regions was used in constructing the liquid phase field in Figure 2(d).

\subsection{Comparison with the $\mathrm{CaO}-\mathrm{YO}_{1.5}-\mathrm{SiO}_{2}$ System}

The substitution of $\mathrm{GdO}_{1.5}$ for $\mathrm{YO}_{1.5}$ in the $\mathrm{CaO}-\mathrm{REO}_{1.5}-\mathrm{SiO}_{2}$ system impacts the stability of the ternary phases and the homogeneity ranges for the solution phases. Compared to the CYS system [7], key differences in the CGS system include (i) the absence of cuspidine at $1400^{\circ} \mathrm{C}$ and $1600^{\circ} \mathrm{C}$, (ii) decreased high temperature stability of silico-carnotite, (iii) an increased range of stable apatite compositions, and (iv) reduced $\mathrm{GdO}_{1.5}$ solubility in the predominantly $\mathrm{CaO}+\mathrm{SiO}_{2}$ liquid. These differences, which arise because $\mathrm{Gd}^{3+}$ is $\sim 4 \%$ larger than $\mathrm{Y}^{3+}[8]$, are discussed in the following paragraphs.

In the $\mathrm{YO}_{1.5}$ system cuspidine is based on the monoclinic $\mathrm{Y}_{4} \mathrm{Al}_{2} \mathrm{O}_{9}$ (YAM) phase. $\mathrm{YAM}$ accommodates substitution of $\mathrm{Si}^{4+}$ for $\mathrm{Al}^{3+}$ up to $\sim 18 \mathrm{~mol} \% \mathrm{SiO}_{2}$ [27] or coupled substitutions of $\mathrm{Ca}^{2+}$ for $\mathrm{Y}^{3+}$ and $\mathrm{Si}^{4+}$ for $\mathrm{Al}^{3+}$ leading to the $\mathrm{AlO}_{1.5}$-free end member with the approximate stoichiometry $\mathrm{Ca}_{2} \mathrm{Y}_{2} \mathrm{Si}_{2} \mathrm{O}_{9}$ [7,24]. The same phase was expected in the CGS system because the CYS cuspidine phase is quite stable (m.p. $>1700^{\circ} \mathrm{C}$ ) and because $\mathrm{Y}_{4} \mathrm{Al}_{2} \mathrm{O}_{9}$ and $\mathrm{Gd}_{4} \mathrm{Al}_{2} \mathrm{O}_{9}$ have similar melting points [28,29] and exhibit similar $\mathrm{SiO}_{2}$ solubility limits [27]. However, the recent CYS investigation revealed that $\mathrm{YO}_{1.5}$ substitutes into the structure more readily than $\mathrm{CaO}$ leading to stable compositions with $\mathrm{Y}$ :Ca ratios slightly greater than one [7]. The associated excess oxygen likely occupies a nominally vacant interstitial site. One possible explanation for this behavior is that the cation sites are slightly undersized to accommodate $\mathrm{Ca}^{2+}$, making it energetically more favorable to incorporate the interstitial oxygen than to maintain the $1: 1 \mathrm{Y}: \mathrm{Ca}$ stoichiometry. In this case, substitutions involving the larger $\mathrm{Gd}^{3+}$ would be less favorable. However, additional details of the solid solution structures are needed in order to more definitively assess the reasons for the differences in stability. 
The melting point of silico-carnotite was reduced from $1732^{\circ} \mathrm{C}$ in the CYS to below $1600^{\circ} \mathrm{C}$ in the CGS system. This observation is generally consistent with the previously reported trend that this phase become less stable as the $\mathrm{RE}^{3+}$ size is increased [1].

The homogeneity range for apatite, Figure 1(a), covers a wider range of RE:Ca ratios in the $\mathrm{GdO}_{1.5^{-}}$than $\mathrm{YO}_{1.5}$-based system. This suggests that the stability of the stoichiometries requiring vacancies for charge balance increases for the larger Gd cation. This conclusion is consistent with data indicating that the enthalpy of formation for the $\mathrm{CaO}$-free apatite stoichiometry increases with the size of the rare earth cation [25]. However, both systems show a tendency to form apatite near the defect-free $\mathrm{Ca}_{2} \mathrm{RE}_{8}\left(\mathrm{SiO}_{4}\right)_{6} \mathrm{O}_{2}$ stoichiometry rather than along the length of the homogeneity range. Additionally, in both systems the equilibria with the liquid phase only involve apatite compositions with $\mathrm{CaO}$ concentrations greater than or equal to $\mathrm{Ca}_{2} \mathrm{RE}_{8}\left(\mathrm{SiO}_{4}\right)_{6} \mathrm{O}_{2}$.

$\mathrm{GdO}_{1.5}$ is less soluble than $\mathrm{YO}_{1.5}$ in the liquid phase. The CGS liquid dissolves up to 14 $\mathrm{mol} \% \mathrm{GdO}_{1.5}$ at $1600^{\circ} \mathrm{C}$ whereas the liquid in the CYS system can dissolve over $25 \mathrm{~mol}^{2} \mathrm{YO}_{1.5}$. Additionally, apatite is the only $\mathrm{GdO}_{1.5}$-rich phase that exists in equilibrium with this liquid while, depending on the Ca:Si ratio, apatite, $\mathrm{Y}_{2} \mathrm{~S}_{2}$, and $\mathrm{C}_{3} \mathrm{Y}_{2} \mathrm{~S}_{3}$ all share equilibrium fields with the liquid in the CYS system. This behavior is likely influenced predominantly by the driving force to precipitate the crystalline phases (e.g., apatite). The equilibrium $\mathrm{REO}_{1.5}$ solubility limit should vary inversely with the magnitude of the free energy of formation for the crystallizing phase. The collective evidence from calorimetry [25] and the phase equilibria suggests that there is a stronger driving force to precipitate apatite in the CGS system compared to the CYS system. The apparently smaller formation energy for the CYS apatite leads to a higher (and more variable) $\mathrm{YO}_{1.5}$ solubility limit in the liquid phase.

The ease of incorporating the $\mathrm{RE}^{3+}$ into the melt structure likely plays a secondary role in determining the solubility limit. $\mathrm{YO}_{1.5}$ and $\mathrm{GdO}_{1.5}$ are known to be modifiers in the glass structure [30]. The solubility of $\mathrm{YO}_{1.5}$ and $\mathrm{GdO}_{1.5}$ in pure amorphous $\mathrm{SiO}_{2}$ is low. $\mathrm{CaO}$ additions partially de-polymerize the $\mathrm{SiO}_{2}$ making it easier to incorporate $\mathrm{Y}^{3+}$ and $\mathrm{Gd}^{3+}$. However, in silicate liquids $\mathrm{Y}^{3+}$ is typically coordinated by six non-bridging oxygens (NBOs) while the larger $\mathrm{Gd}^{3+}$ has a higher coordination number [30,31]. The higher $\mathrm{Y}^{3+}$ field strength also exerts a stronger influence on the local structure. Thus, for a given fraction of NBOs (i.e. the 'openness' 
of the melt structure, determined by the modifier content) $\mathrm{Y}^{3+}$ should be more readily accommodated than $\mathrm{Gd}^{3+}$.

\subsection{Implications for TBC Reactivity with CMAS}

Efforts to develop improved thermal barrier coatings materials for mitigating CMAS degradation aim to maximize the volume of rapidly crystallizing phases $\left(\mathrm{V}_{\text {crys }}\right)$ formed per volume of dissolved thermal barrier coating $\left(\mathrm{V}_{\mathrm{TBC}}\right)$. In this context apatite is a desirable reaction product because it contains a high fraction of melt constituents $\left(\mathrm{CaO}+\mathrm{SiO}_{2}\right)$ and precipitates rapidly upon TBC dissolution [5,32]. Systems favoring the crystallization of slower-growing silicates including garnet $[6,33]$ and cuspidine [34] or which have a high $\mathrm{REO}_{1.5}$ solubility in the melt do not arrest melt infiltration as effectively as those that only form apatite and have low solubility limits in the melt [6].

Efforts to make quantitative comparisons between the behaviors of TBC materials based on tests with individual 'representative' deposits are complicated by the wide variations in the anticipated deposit compositions. It is more effective to develop an understanding of the reactions by examining the underlying phase equilibria. The long-term goal, advanced by this and related studies, is to develop a thermodynamic database capable of accurately predicting the reactions occurring in higher-order (6+ component) systems. However, in the absence of such a tool preliminary assessments can me made based on the phase equilibria in the sub-systems containing the important phases involved in the reactions (i.e. apatite and a liquid containing predominantly $\mathrm{CaO}$ and $\mathrm{SiO}_{2}$ ). Comparisons between the $1600^{\circ} \mathrm{C}$ isothermal sections for the CGS and CYS systems provides several insights into the differences in behavior for $\mathrm{GdO}_{1.5^{-}}$and $\mathrm{YO}_{1.5}$-based coating materials upon reaction with silicate deposits containing varied Ca:Si ratios:

(i) The ratio of $\mathrm{V}_{\text {crys }}: \mathrm{V}_{\mathrm{TBC}}$ for apatite precipitation is determined in part by the ratio Ca:RE in the apatite phase. The phase equilibria indicate that although the stable Ca:Gd range for apatite is wider than $\mathrm{Ca}: \mathrm{Y}$, the apatite compositions that exist in equilibrium with the melt for both systems fall in a smaller subset at the CaO-rich end of the homogeneity range. This finding is consistent with measurements of the equilibrium apatite compositions upon reaction between prospective $\mathrm{TBC}$ systems and $\mathrm{C}(\mathrm{M}) \mathrm{AS}$ melts [35].

(ii) Although ternary phases beside apatite are stable in the CGS system, the absence of the cuspidine phase, lower melting temperature for $\mathrm{C}_{3} \mathrm{G}_{2} \mathrm{~S}_{3}$, and lack of an equilibrium between 
GdDS and the liquid phase at $1600^{\circ} \mathrm{C}$ suggest that apatite is more likely to be the predominant reaction product for a $\mathrm{GdO}_{1.5^{-}}$compared to $\mathrm{YO}_{1.5}$-based $\mathrm{TBC}$. This means that for an equivalent $\mathrm{REO}_{1.5}$ concentration in the coating materials, coatings containing $\mathrm{GdO}_{1.5}$ would be more likely to form apatite than those containing $\mathrm{YO}_{1.5}$.

(iii) The lower solubility limit of $\mathrm{GdO}_{1.5}$ in the melt compared to $\mathrm{YO}_{1.5}$ implies that the dissolution of $\mathrm{GdO}_{1.5}$-based TBC would saturate the melt and initiate apatite precipitation more readily than an equivalent $\mathrm{YO}_{1.5}$-based TBC.

The differences between the phase equilibria for the $\mathrm{YO}_{1.5^{-}}$and $\mathrm{GdO}_{1.5}-\mathrm{CaO}-\mathrm{SiO}_{2}$ systems are not likely to influence to comparative behavior of rare earth stabilized TBC materials (i.e. $7 \mathrm{YSZ}$ vs. equivalent $\mathrm{GdO}_{1.5}$-stbilized tetragonal $\mathrm{ZrO}_{2}$ ). The differences will be more pronounced for coatings with higher $\mathrm{REO}_{1.5}$ content. Specifically, $\mathrm{Gd}_{2} \mathrm{Zr}_{2} \mathrm{O}_{7}$ should offer improved resistance to molten silicate degradation compared to $\mathrm{Y}_{4} \mathrm{Zr}_{3} \mathrm{O}_{12}$. This conclusion is consistent with RE cation-size-dependent reaction behavior between thermal barrier oxides and representative multi-component silicate melts [6,35].

\section{CONCLUSIONS}

This study elucidated the $\mathrm{CaO}-\mathrm{GdO}_{1.5}-\mathrm{SiO}_{2}$ phase equilibria at $1400^{\circ} \mathrm{C}$ and $1600^{\circ} \mathrm{C}$. Key findings include:

- At $1400^{\circ} \mathrm{C}$ silicocarnotite $\left(\mathrm{C}_{3} \mathrm{G}_{2} \mathrm{~S}_{3}\right)$ and cyclosilicate $\left(\mathrm{C}_{3} \mathrm{G}_{2} \mathrm{~S}_{6}\right)$ are stable line compounds while apatite exhibits a solid solution homogeneity range. Of these, only apatite is stable at $1600^{\circ} \mathrm{C}$.

- Although the crystal chemistry of the apatite phase permits compositions in the range $\mathrm{Ca}_{4} \mathrm{Gd}_{6}\left(\mathrm{SiO}_{4}\right)_{6} \mathrm{O}$ to $\mathrm{Gd}_{9.33}\left(\mathrm{SiO}_{4}\right)_{6} \mathrm{O}_{2}$, the most $\mathrm{CaO}$-rich compositions are not stable relative to the equilibrium with other phases. Specifically, the stable range extends from $\mathrm{Ca}_{2.75} \mathrm{Gd}_{7.25}\left(\mathrm{SiO}_{4}\right)_{6} \mathrm{O}_{1.625}$ to $\mathrm{Gd}_{9.33}\left(\mathrm{SiO}_{4}\right)_{6} \mathrm{O}_{2}$.

- $\mathrm{Ca}_{2} \mathrm{SiO}_{4}$ dissolves up to $8.5 \mathrm{~mol} \% \mathrm{GdO}_{1.5}$ at $1400^{\circ} \mathrm{C}$ and up to $14 \mathrm{~mol} \% \mathrm{GdO}_{1.5}$ at $1600^{\circ} \mathrm{C}$. The $\mathrm{Gd}^{3+}$ likely substitutes onto the $\mathrm{Ca}^{2+}$ sites with corresponding cation vacancy formation to maintain charge balance.

- At $1600^{\circ} \mathrm{C}$ the liquid can coexist with crystalline $\mathrm{SiO}_{2}$, apatite, and $(\mathrm{C}, \mathrm{G})_{2} \mathrm{~S}$. The wide range of liquid compositions stable in contact with apatite indicates that the latter phase is 
likely to be the predominant crystallization product for reactions between $\mathrm{GdO}_{1.5}$-based TBCs and $\mathrm{CaO}+\mathrm{SiO}_{2}$ based melts.

The insights from this work aid in developing new phase stable oxides for functional applications and contribute to developing phase equilibrium-based tools for designing improved thermal barrier coatings.

\section{ACKNOWLEDGEMENTS}

Research supported by ONR grant N00014-16-1-2702 and NAVAIR STTR Phase II N00014-12-M-0340, both monitored by Dr. David Shifler. The work made use of the MRL Shared Experimental Facilities supported by the MRSEC Program of the NSF under Award No. DMR 1121053; a member of the NSF-funded Materials Research Facilities Network (www.mrfn.org). The funding agencies were not involved in the study design, the collection, analysis and interpretation of the data, or the decision to publish. The authors are grateful to G.G.E. Seward (UCSB) for assistance with EPMA analysis, A. Velasco-Hogan and S. Molakalapalli (UCSB) for assistance with specimen preparation, and W. Zhang and N. Hatcher

(QuesTek Innovations) for discussions regarding their thermodynamic assessment of the CGS system. 


\section{REFERENCES}

1. F. Piccinelli, A. Lausi, A. Speghini, and M. Bettinelli, "Crystal structure study of new lanthanide silicates with silico-carnotite structure," J. Solid State Chem., 194 233-37. (2012). 10.1016/j.jssc.2012.05.012

2. S. Nakayama, T. Kageyama, H. Aono, and Y. Sadaoka, "Ionic-Conductivity of Lanthanoid Silicates, $\mathrm{Ln}_{10}(\mathrm{SiO} 4)_{6} \mathrm{O}_{3}(\mathrm{Ln}=\mathrm{La}, \mathrm{Nd}, \mathrm{Sm}, \mathrm{Gd}$, Dy, Y, Ho, Er and $\mathrm{Yb})$," $J$. Mater. Chem., 5[11] 1801-05. (1995). 10.1039/jm9950501801

3. P.R. Slater, J.E.H. Sansom, and J.R. Tolchard, "Development of apatite-type oxide ion conductors," Chem. Rec., 4[6] 373-84. (2004). 10.1002/tcr.20028

4. Z.X. Qu, T.D. Sparks, W. Pan, and D.R. Clarke, "Thermal conductivity of the gadolinium calcium silicate apatites: Effect of different point defect types," Acta Mater., 59[10] 3841-50. (2011). 10.1016/J.Actamat.2011.03.008

5. S. Kramer, J. Yang, and C.G. Levi, "Infiltration-inhibiting reaction of gadolinium zirconate thermal barrier coatings with CMAS melts," J. Am. Ceram. Soc., 91[2] 576-83. (2008). 10.1111/J.1551-2916.2007.02175.X

6. D.L. Poerschke and C.G. Levi, "Effects of substitution and temperature on the interaction between thermal barrier oxides and molten CMAS," J. Eur. Ceram. Soc., 35[2] 681-91. (2015). 10.1016/j.jeurceramsoc.2014.09.006

7. D.L. Poerschke, T.L. Barth, O. Fabrichnaya, and C.G. Levi, "Phase equilibria and crystal chemistry in the calcia-silica-yttria system," J. Eur. Ceram. Soc., 36[7] 1743-54. (2016). 10.1016/j.jeurceramsoc.2016.01.046

8. R.D. Shannon and C.T. Prewitt, "Effective Ionic Radii in Oxides and Fluorides," Acta Crystall B-Stru, B 25 925-\&. (1969). 10.1107/S0567740869003220

9. M. Zinkevich, "Thermodynamics of rare earth sesquioxides," Progress in Materials Science, 52[4] 597-647. (2007).

10. V. Swamy, S.K. Saxena, B. Sundman, and J. Zhang, "A Thermodynamic Assessment of Silica Phase-Diagram," J Geophys Res-Sol Ea, 99[B6] 11787-94. (1994). Doi 10.1029/93jb02968

11. R.B. Sosman, "The phases of silica,"). New Brunswick, N.J.: Rutgers University Press. (1965).

12. M. Hillert, B. Sundman, and X. Wang, "An assessment of the $\mathrm{CaO}-\mathrm{SiO}_{2}$ system," Metallurgical and Materials Transactions B, 21[2] 303-12-12. (1990). $\underline{10.1007 / \mathrm{bf02664198}}$

13. N.A. Toropov and N.F. Fedorov, "Equilibrium Diagram of the $\mathrm{Ca}_{2} \mathrm{SiO}_{4}-\mathrm{Y}_{4}\left(\mathrm{SiO}_{4}\right)_{3}$ System," Russ. J. Inorg. Chem., 10[1] 358-59. (1965).

14. J.D. Tewhey and P.C. Hess, "The two phase region in the $\mathrm{CaO}-\mathrm{SiO}_{2}$ system: experimental data and thermodynamic analysis," Phys. Chem. Glasses, 20[3] 41-53. (1979). 
15. V.B.M. Hageman, G.J.K. van den Berg, H.J. Janssen, and H.A.J. Oonk, "A reinvestigation of liquid immiscibility in the $\mathrm{SiO}_{2}-\mathrm{CaO}$ system," Phys. Chem. Glasses, 27[2] 100-06. (1986).

16. N.A. Toropov, F.Y. Galakhov, and S.F. Konovalova, "Silicates of the rare earth elements: communication 2. phase diagram of the binary system gadolinium oxide - silica," Russ. Chem. Bull., 10[4] 497-501. (1961). 10.1007/bf00909108

17. J. Felsche, "Polymorphism and crystal data of the rare-earth disilicates of type $\mathrm{RE}_{2} \mathrm{Si}_{2} \mathrm{O}_{7}$," Journal of the Less Common Metals, 21[1] 1-14. (1970).

18. L.M. Lopato, "Highly refractory oxide systems containing oxides of rare-earth elements," Ceramurgia International, 2[1] 18-32. (1976). 10.1016/0390-5519(76)90004-1

19. E.V. Doronin, M.A. Grintsova, E.P. Shevyakova, N.P. Konotop, N.P. Odeichuk, and A.S. Kamenev, "Phase relations in the $\mathrm{CaO}-\mathrm{Al}_{2} \mathrm{O}_{3}-\mathrm{Gd}_{2} \mathrm{O}_{3}$ System," Inorganic Materials, 27[9] 1564-67. (1991).

20. T.L. Barry, V.S. Stubican, and R. Roy, "Phase Equilibria in System $\mathrm{CaO}-\mathrm{Yb}_{2} \mathrm{O}_{3}$," J. Am. Ceram. Soc., 49[12] 667-\&. (1966). 10.1111/J.1151-2916.1966.Tb13196.X

21. D.D. Gulamova, S.N. Novoselova, and B.S. Nigmanov, "Phase Correlations in the Zro2Cao-Gd2o3 Triple System Depending on Fusion Synthesis and Solid-Phase Reactions," Russ. J. Inorg. Chem., 37[12] 1455-59. (1992).

22. J. Ito, "Silicate apatites and oxyapatites," The American Mineralogist, 53 890-907. (1968).

23. H. Yamane, T. Nagasawa, M. Shimada, and T. Endo, "Ca $\mathrm{Y}_{2}\left(\mathrm{Si}_{3} \mathrm{O}_{9}\right)_{2}, "$ Acta Crystallogr C, 53 1533-36. (1997). 10.1107/S010827019700721x

24. I. Warshaw and R. Roy, "New Family of Rare Earth Compounds," Inorg. Chem., 1[3] 719-\&. (1962). 10.1021/Ic50003a059

25. A.S. Risbud, K.B. Helean, M.C. Wilding, P. Lu, and A. Navrotsky, "Enthalpies of formation of lanthanide oxyapatite phases," J. Mater. Res., 16[10] 2780-83. (2001). $10.1557 / \mathrm{Jmr} .2001 .0381$

26. J.A. Fahey, W.J. Weber, and F.J. Rotella, "An X-Ray and Neutron Powder Diffraction Study of the $\mathrm{Ca}_{2+\mathrm{X}} \mathrm{Nd}_{8-\mathrm{X}}\left(\mathrm{SiO}_{4}\right)_{6} \mathrm{O}_{2-0.5 \mathrm{X}}$ System," J. Solid State Chem., 60[2] 145-58. (1985). 10.1016/0022-4596(85)90106-9

27. U. Kolitsch, H. Seifert, and F. Aldinger, "Phase relationships in the systems $\mathrm{RE}_{2} \mathrm{O}_{3}$ $\mathrm{Al}_{2} \mathrm{O}_{3}-\mathrm{SiO}_{2}(\mathrm{RE}=$ rare earth element, Y, and Sc)," J. Phase Equilib., 19[5] 426-33. (1998). Doi 10.1361/105497198770341905

28. S. Lakiza, O. Fabrichnaya, C. Wang, M. Zinkevich, and F. Aldinger, "Phase diagram of the $\mathrm{ZrO}_{2}-\mathrm{Gd}_{2} \mathrm{O}_{3}-\mathrm{Al}_{2} \mathrm{O}_{3}$ system," J. Eur. Ceram. Soc., 26[3] 233-46. (2006). Doi 10.1016/J.Jeurceramsoc.2004.11.011

29. O. Fabrichnaya, H.J. Seifert, R. Weiland, T. Ludwig, F. Aldinger, and A. Navrotsky, "Phase equilibria and thermodynamics in the $\mathrm{Y}_{2} \mathrm{O}_{3}-\mathrm{Al}_{2} \mathrm{O}_{3}-\mathrm{SiO}_{2}$-system," Z. Metallkd., 92[9] 1083-97. (2001). 
30. C.W. Ponader and G.E. Brown, "Rare-Earth Elements in Silicate Glass Melt Systems .1. Effects of Composition on the Coordination Environments of La, Gd, and Yb," Geochim. Cosmochim. Acta, 53[11] 2893-903. (1989). 10.1016/0016-7037(89)90166-X

31. J. Wang, W.S. Brocklesby, J.R. Lincoln, J.E. Townsend, and D.N. Payne, "Local Structures of Rare-Earth Ions in Glasses - the Crystal-Chemistry Approach," J. NonCryst. Solids, 163[3] 261-67. (1993). 10.1016/0022-3093(93)91303-K

32. C.G. Levi, J.W. Hutchinson, M.-H. Vidal-Sétif, and C.A. Johnson, "Environmental degradation of thermal-barrier coatings by molten deposits," MRS Bulletin, 37[10] 93241. (2012). 10.1557/mrs.2012.230

33. N.K. Eils, P. Mechnich, and W. Braue, "Effect of CMAS Deposits on MOCVD Coatings in the System $\mathrm{Y}_{2} \mathrm{O}_{3}-\mathrm{ZrO}_{2}$ : Phase Relationships," J. Am. Ceram. Soc., 96[10] 3333-40. (2013). 10.1111/jace.12502

34. D.L. Poerschke, D.D. Hass, S. Eustis, G.G.E. Seward, J.S. Van Sluytman, and C.G. Levi, "Stability and CMAS Resistance of Ytterbium-Silicate/Hafnate EBCs/TBC for SiC Composites," J. Am. Ceram. Soc., 98[1] 278-86. (2015). 10.1111/jace.13262

35. D.L. Poerschke, T.L. Barth, and C.G. Levi, "Equilibrium relationships between thermal barrier oxides and silicate melts," Acta Mater., 120 302-14. (2016).

10.1016/j.actamat.2016.08.077 


\section{TABLES}

Table 1: Binary and Ternary $\mathrm{CaO}-\mathrm{SiO}_{2}-\mathrm{GdO}_{1.5}$ Phases

\begin{tabular}{|c|c|c|c|}
\hline Formula & Abbreviation & Phase Name & Space Group \\
\hline $\mathrm{CaO}$ & $\mathrm{C}$ & Lime & $\mathrm{Fm} 3 \mathrm{~m}$ \\
\hline $\mathrm{SiO}_{2}$ & $\mathrm{~S}$ & $\begin{array}{c}\alpha-, \beta \text {-Quartz } \\
\text { HP-Tridymite } \\
\beta \text {-Cristobalite }\end{array}$ & $\begin{array}{c}\mathrm{P}_{2} 21, \mathrm{P}_{2} 22 \\
\mathrm{P}_{3} / \mathrm{mmc} \\
\mathrm{Fd} 3 \mathrm{~m}\end{array}$ \\
\hline \multirow{5}{*}{$\mathrm{GdO}_{1.5}$} & \multirow{5}{*}{ G } & $\mathrm{C}$ & Ia $\overline{3}$ \\
\hline & & B & $\mathrm{C} 2 / \mathrm{m}$ \\
\hline & & A & $\mathrm{P} \overline{3} \mathrm{~m} 1$ \\
\hline & & $\mathrm{H}$ & $\mathrm{P}_{3} / \mathrm{mmc}$ \\
\hline & & $\mathrm{X}$ & $\operatorname{Im} \overline{3} \mathrm{~m}$ \\
\hline \multirow[b]{2}{*}{$\mathrm{CaSiO}_{3}$} & \multirow[b]{2}{*}{ CS } & Wollastnnite $(\beta)$ & $\mathrm{P} \overline{1}$ \\
\hline & & $\begin{array}{l}\text { Parawollastonite (2M) } \\
\text { Pseudowollastonite }(\alpha)\end{array}$ & $\begin{array}{l}\mathrm{P} 12_{1} / \mathrm{c} 1 \\
\mathrm{C} 2 / \mathrm{c}\end{array}$ \\
\hline $\mathrm{Ca}_{3} \mathrm{Si}_{2} \mathrm{O}_{7}$ & $\mathrm{C}_{3} \mathrm{~S}_{2}$ & Rankinite & $\mathrm{P} 12_{1} / \mathrm{c} 1$ \\
\hline $\mathrm{Ca}_{2} \mathrm{SiO}_{4}$ & $\mathrm{C}_{2} \mathrm{~S}$ & $\begin{array}{c}\text { Larnite } \\
\text { Calcio-Olivine }(\gamma)\end{array}$ & $\begin{array}{l}\mathrm{P} 12_{1} / \mathrm{c} 1 \\
\text { Pnma }\end{array}$ \\
\hline$(\mathrm{Ca}, \mathrm{Gd})_{2} \mathrm{SiO}_{4}$ & $(\mathrm{CG})_{2} \mathrm{~S}$ & $\begin{array}{c}\alpha-\mathrm{Ca}_{2} \mathrm{SiO}_{4} \\
\alpha^{\prime}-\mathrm{Ca}_{2} \mathrm{SiO}_{4} \\
\end{array}$ & $\begin{array}{c}\mathrm{P} 6_{3} / \mathrm{mmc} \\
\mathrm{Pnma}\end{array}$ \\
\hline$(\mathrm{Ca}, \mathrm{Gd})_{3} \mathrm{SiO}_{5}$ & $\mathrm{C}_{3} \mathrm{~S}$ & Hatrurite & $\mathrm{R} 3 \mathrm{~m}$ \\
\hline \multirow{2}{*}{$\mathrm{Gd}_{2} \mathrm{Si}_{2} \mathrm{O}_{7}$} & \multirow{2}{*}{$\mathrm{G}_{2} \mathrm{~S}_{2}$} & Gadolinium Disilicate $(\alpha)$ & $\mathrm{P} \overline{1}$ \\
\hline & & Gadolinium Disilicate $(\delta)$ & Pna2 ${ }_{1}$ \\
\hline $\mathrm{Gd}_{2} \mathrm{SiO}_{5}$ & $\mathrm{G}_{2} \mathrm{~S}$ & Gadolinium Monosilicate (X2) & $\mathrm{P} 2{ }_{1} / \mathrm{c}$ \\
\hline $\mathrm{CaGd}_{4} \mathrm{O}_{7}$ & $\mathrm{CG}_{4}$ & Calcium Gadolinium Oxide & $\mathrm{C} 2 / \mathrm{m}$ \\
\hline$(\mathrm{Ca}, \mathrm{Gd})_{4} \mathrm{Gd}_{6}\left(\mathrm{SiO}_{4}\right)_{6} \mathrm{O}_{2}$ & Ap & Apatite & $\mathrm{P} 6_{3} / \mathrm{m}$ \\
\hline $\mathrm{Ca}_{3} \mathrm{Gd}_{2} \mathrm{Si}_{3} \mathrm{O}_{12}$ & $\mathrm{C}_{3} \mathrm{G}_{2} \mathrm{~S}_{3}$ & Silicocarnotite (SC) & Pnma \\
\hline $\mathrm{Ca}_{3} \mathrm{Gd}_{2} \mathrm{Si}_{6} \mathrm{O}_{18}$ & $\mathrm{C}_{3} \mathrm{G}_{2} \mathrm{~S}_{6}$ & CaGd-cyclosilicate (CyS) & $\mathrm{C} 2 / \mathrm{c}$ \\
\hline
\end{tabular}


Table 2: $\mathrm{CaO}-\mathrm{SiO}_{2}-\mathrm{GdO}_{1.5}$ Compositions and Phase Relationships

\begin{tabular}{cccc}
\hline ID & $\begin{array}{c}\text { Nominal } \\
\text { Composition }\end{array}$ & \multicolumn{2}{c}{ Observed Phase(s) } \\
\hline 1 & $\mathrm{G}_{64} \mathrm{~S}_{36}$ & $\mathrm{G}_{2} \mathrm{~S}_{2}+\mathrm{Ap}$ & $1600^{\circ} \mathrm{C}$ \\
2 & $\mathrm{G}_{55} \mathrm{~S}_{45}$ & $\mathrm{G}_{2} \mathrm{~S}+\mathrm{Ap}$ & $\mathrm{G}_{2} \mathrm{~S}_{2}+\mathrm{Ap}$ \\
3 & $\mathrm{C}_{24} \mathrm{G}_{37} \mathrm{~S}_{40}$ & $\mathrm{CS}+\mathrm{C}_{3} \mathrm{G}_{2} \mathrm{~S}_{3}+\mathrm{Ap}$ & $\mathrm{Liq}+(\mathrm{CG})_{2} \mathrm{~S}+\mathrm{Ap}$ \\
4 & $\mathrm{C}_{25} \mathrm{G}_{38} \mathrm{~S}_{38}$ & $\mathrm{C}_{3} \mathrm{G}_{2} \mathrm{~S}_{3}+\mathrm{Ap}$ & $\mathrm{Liq}+(\mathrm{CG})_{2} \mathrm{~S}+\mathrm{Ap}$ \\
5 & $\mathrm{C}_{38} \mathrm{G}_{25} \mathrm{~S}_{38}$ & $\mathrm{C}_{3} \mathrm{G}_{2} \mathrm{~S}_{3}$ & $\mathrm{Liq}+(\mathrm{CG})_{2} \mathrm{~S}+\mathrm{Ap}$ \\
6 & $\mathrm{C}_{54} \mathrm{G}_{10} \mathrm{~S}_{36}$ & $(\mathrm{CG})_{2} \mathrm{~S}+\mathrm{CS}+\mathrm{SC}$ & $\mathrm{Liq}+(\mathrm{CG})_{2} \mathrm{~S}$ \\
7 & $\mathrm{C}_{3} \mathrm{G}_{64} \mathrm{~S}_{33}$ & $\mathrm{G}_{2} \mathrm{~S}+\mathrm{Ap}+\mathrm{GdO}_{1.5}$ & $\mathrm{G}_{2} \mathrm{~S}+\mathrm{Ap}+\mathrm{GdO}_{1.5}$ \\
8 & $\mathrm{C}_{3} \mathrm{G}_{45} \mathrm{~S}_{52}$ & $\mathrm{G}_{2} \mathrm{~S}_{2}+\mathrm{Ap}+\mathrm{SiO}_{2}$ & $\mathrm{G}_{2} \mathrm{~S}_{2}+\mathrm{Ap}+\mathrm{SiO}_{2}$ \\
9 & $\mathrm{C}_{15} \mathrm{G}_{25} \mathrm{~S}_{60}$ & $\mathrm{CyS}+\mathrm{Ap}+\mathrm{SiO}_{2}$ & $\mathrm{Liq}+\mathrm{Ap}+\mathrm{SiO}_{2}$ \\
10 & $\mathrm{C}_{20} \mathrm{G}_{50} \mathrm{~S}_{30}$ & $(\mathrm{CG})_{2} \mathrm{~S}+\mathrm{Ap}+\mathrm{GdO}_{1.5}$ & $(\mathrm{CG})_{2} \mathrm{~S}+\mathrm{Ap}+\mathrm{GdO}_{1.5}$ \\
11 & $\mathrm{C}_{60} \mathrm{G}_{30} \mathrm{~S}_{10}$ & $\mathrm{CaO}+\mathrm{C}_{3} \mathrm{~S}+\mathrm{GdO}_{1.5}$ & $\mathrm{CaO}+\mathrm{C}_{3} \mathrm{~S}+\mathrm{CG}_{4}$ \\
12 & $\mathrm{C}_{63} \mathrm{G}_{10} \mathrm{~S}_{25}$ & $(\mathrm{CG})_{2} \mathrm{~S}+\mathrm{C}_{3} \mathrm{~S}+\mathrm{GdO}_{1.5}$ & $(\mathrm{CG})_{2} \mathrm{~S}+\mathrm{C}_{3} \mathrm{~S}+\mathrm{CG}_{4}$ \\
13 & $\mathrm{C}_{30} \mathrm{G}_{10} \mathrm{~S}_{60}$ & $\mathrm{Liq}+\mathrm{SiO}_{2}+\mathrm{C}_{3} \mathrm{G}_{2} \mathrm{~S}_{6}$ & $\mathrm{Two} \mathrm{Liqs}$ \\
14 & $\mathrm{C}_{32} \mathrm{G}_{20} \mathrm{~S}_{48}$ & $\mathrm{CS}+\mathrm{C}_{3} \mathrm{G}_{2} \mathrm{~S}_{6}+\mathrm{Ap}_{2}$ & $\mathrm{Liq}+\mathrm{Ap}$ \\
15 & $\mathrm{C}_{27} \mathrm{G}_{7} \mathrm{~S}_{70}$ & -- & $\mathrm{Two} \mathrm{Liqs}+\mathrm{SiO}_{2}$ \\
\hline
\end{tabular}

a Compositions are reported as mole percent of the constituent oxides based on a single cation formulas. 
Table 3: Composition Measurements for Solution Phases ${ }^{\text {a }}$

\begin{tabular}{|c|c|c|c|c|c|c|c|}
\hline \multirow{3}{*}{ Phase } & \multirow{3}{*}{ ID } & \multicolumn{6}{|c|}{ Composition $(\mathbf{m o l} \%)^{\mathrm{a}}$} \\
\hline & & \multicolumn{3}{|c|}{$1400^{\circ} \mathrm{C}$} & \multicolumn{3}{|c|}{$1600^{\circ} \mathrm{C}$} \\
\hline & & $\mathrm{CaO}$ & $\mathrm{SiO}_{2}$ & $\mathrm{GdO}_{1.5}$ & $\mathrm{CaO}$ & $\mathrm{SiO}_{2}$ & $\mathbf{G d O}_{1.5}$ \\
\hline \multirow{10}{*}{ Apatite } & 1 & 0 & 40 & 60 & 0.0 & 39.6 & 60.3 \\
\hline & 2 & 0.0 & 38.6 & 61.4 & 0.0 & 38.8 & 61.2 \\
\hline & 3 & 15.2 & 36.7 & 48.1 & 16.6 & 37.4 & 46.0 \\
\hline & 4 & 17 & 38 & 45 & 17 & 38 & 45 \\
\hline & 5 & -- & -- & -- & 16.9 & 37.3 & 45.8 \\
\hline & 7 & 12 & 38 & 50 & 11 & 38 & 51 \\
\hline & 8 & 12 & 38 & 50 & 11 & 38 & 51 \\
\hline & 9 & 13 & 37 & 50 & 13.0 & 36.5 & 50.5 \\
\hline & 10 & 13 & 37 & 50 & 13.6 & 37.4 & 49.0 \\
\hline & 14 & 15 & 37 & 48 & 13.6 & 36.7 & 49.7 \\
\hline \multirow{5}{*}{$(\mathrm{Ca}, \mathrm{Gd})_{2} \mathrm{SiO}_{4}$} & 3 & -- & -- & -- & 49 & 37 & 14 \\
\hline & 5 & -- & -- & -- & 50 & 37 & 13 \\
\hline & 6 & 57.7 & 34.0 & 8.3 & 54 & 35 & 11 \\
\hline & 10 & 61 & 34 & 5 & 59.2 & 34.6 & 6.2 \\
\hline & 12 & 65.3 & 33.3 & 1.5 & 62 & 33 & 5 \\
\hline \multirow{2}{*}{$\mathrm{CaGd}_{4} \mathrm{O}_{7}$} & 11 & \multirow{2}{*}{\multicolumn{3}{|c|}{$\begin{array}{c}\text { Phase } \\
\text { not stable }\end{array}$}} & 16 & 1 & 83 \\
\hline & 12 & & & & 14 & 1 & 85 \\
\hline \multirow{2}{*}{$(\mathrm{Ca}, \mathrm{Gd})_{3} \mathrm{SiO}_{5}$} & 11 & 73 & 25 & 2 & 70 & 28 & 3 \\
\hline & 12 & 72.7 & 26.6 & 0.8 & 71 & 26 & 3 \\
\hline \multirow{3}{*}{ Silicocarnotite } & 3 & 37.2 & 36.4 & 26.4 & \multirow{3}{*}{\multicolumn{3}{|c|}{$\begin{array}{c}\text { Phase } \\
\text { not stable }\end{array}$}} \\
\hline & 4 & 38 & 38 & 25 & & & \\
\hline & 6 & 38.1 & 37.1 & 24.8 & & & \\
\hline \multirow{3}{*}{ Cyclosilicate } & 9 & 27 & 55 & 18 & \multirow{3}{*}{\multicolumn{3}{|c|}{$\begin{array}{c}\text { Phase } \\
\text { not stable }\end{array}$}} \\
\hline & 13 & 27.8 & 53.9 & 18.3 & & & \\
\hline & 14 & 27.6 & 53.9 & 18.6 & & & \\
\hline \multirow{3}{*}{$\mathrm{GdO}_{1.5}$} & 10 & & & & 0.7 & 0.1 & 999.3 \\
\hline & 11 & 8 & 0 & 92 & \multirow{2}{*}{\multicolumn{3}{|c|}{$\begin{array}{c}\text { Phase } \\
\text { not stable }\end{array}$}} \\
\hline & 12 & 7 & 0 & 93 & & & \\
\hline $\mathrm{CaO}$ & 11 & 97 & 0 & 3 & 98 & 0 & 2 \\
\hline \multirow{6}{*}{ Liquid } & 5 & -- & -- & -- & 48.3 & 45.7 & 6.1 \\
\hline & 6 & -- & -- & -- & 48 & 45 & 7 \\
\hline & 9 & -- & -- & -- & 26.7 & 59.5 & 13.8 \\
\hline & 13 & 38 & 59 & 3 & 27.9 & 60.8 & 11.3 \\
\hline & 14 & -- & -- & -- & 35.6 & 52.5 & 11.9 \\
\hline & 15 & -- & -- & -- & 29.6 & 61.3 & 9.2 \\
\hline
\end{tabular}

\footnotetext{
a Values reported to $0.1 \mathrm{~mol} \%$ and $1 \mathrm{~mol} \%$ precision measured by EPMA and TEM/SEM-EDS, respectively.
} 


\section{FIGURES}
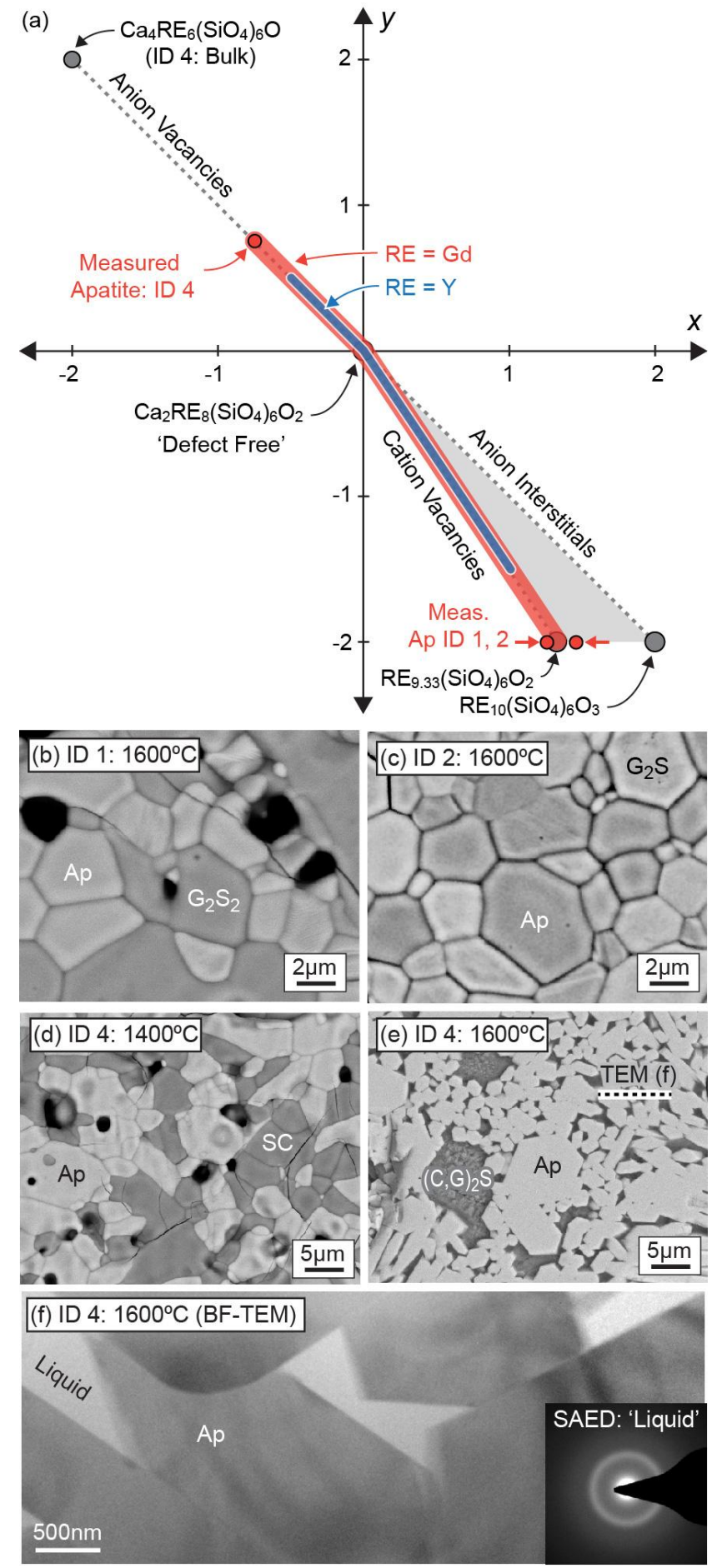

Figure 1: The theoretical range for ionic substitutions in apatite, governed by $\mathrm{RE}_{8+\mathrm{x}} \mathrm{Ca}_{2+\mathrm{y}}\left(\mathrm{SiO}_{4}\right)_{6} \mathrm{O}_{2+3 \mathrm{x} / 2+\mathrm{y}}$, is shown with dashed lines and light shading in (a), adapted from Qu et al. [4]. The $\mathrm{GdO}_{1.5}$-based apatite is stable (b,c) in the $\mathrm{CaO}$-free limit but (d-f) does not extend to the $\mathrm{CaO}$ rich limit of $\mathrm{Ca}_{4} \mathrm{Gd}_{6}\left(\mathrm{SiO}_{4}\right)_{6} \mathrm{O}$. Previously reported data for the $\mathrm{YO}_{1.5}$-based apatite homogeneity range is overlaid in (a) for comparison [7]. 


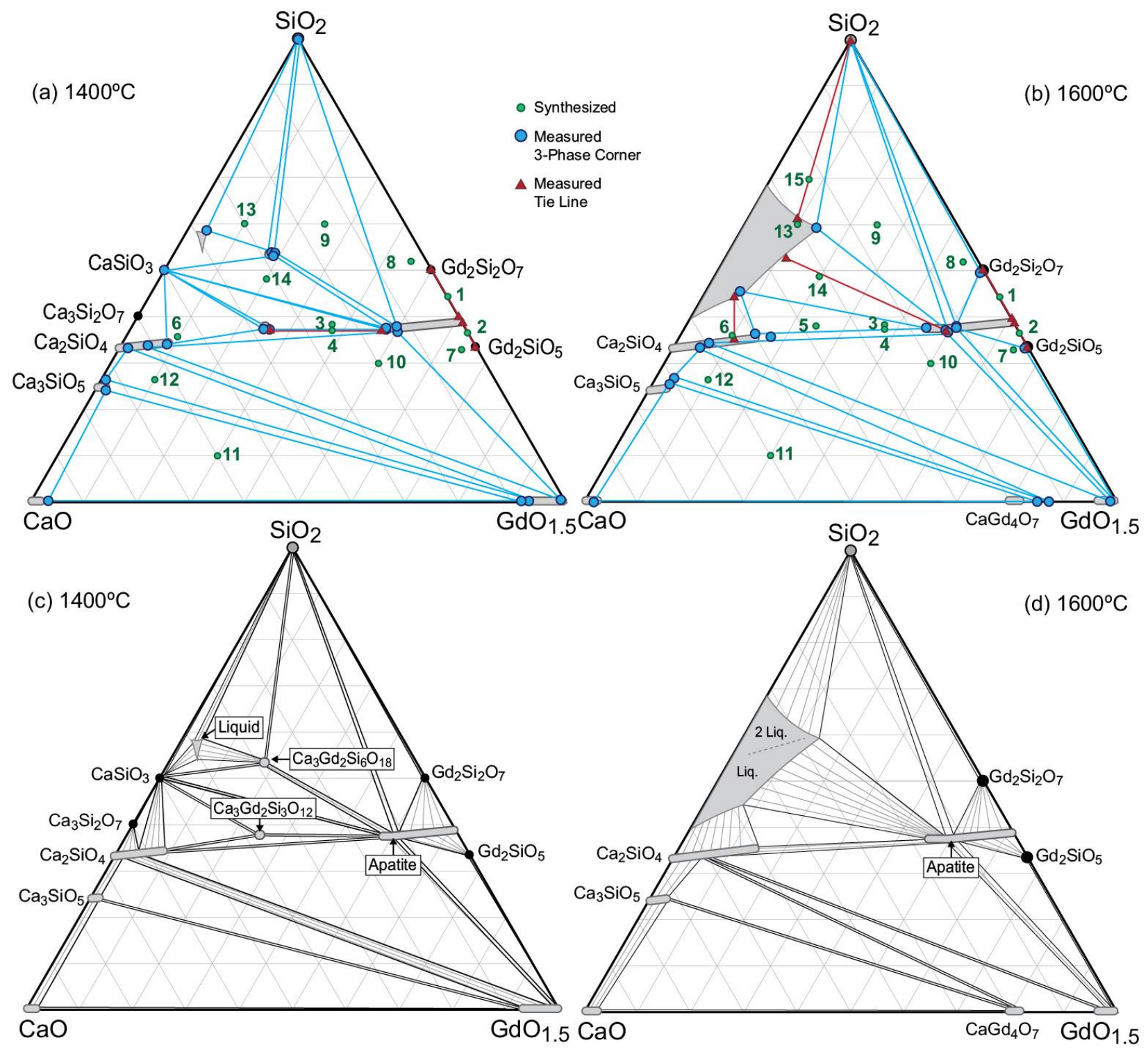

Figure 2: $\mathrm{CaO}-\mathrm{GdO}_{1.5}-\mathrm{SiO}_{2}$ ternary isothermal sections. The experimental data, Table 2 and Table 3, define the three-phase triangles and tie lines at (a) $1400^{\circ} \mathrm{C}$ and (b) $1600^{\circ} \mathrm{C}$ that were used to construct the $(\mathrm{c}, \mathrm{d})$ complete diagrams with inferred tie lines. 

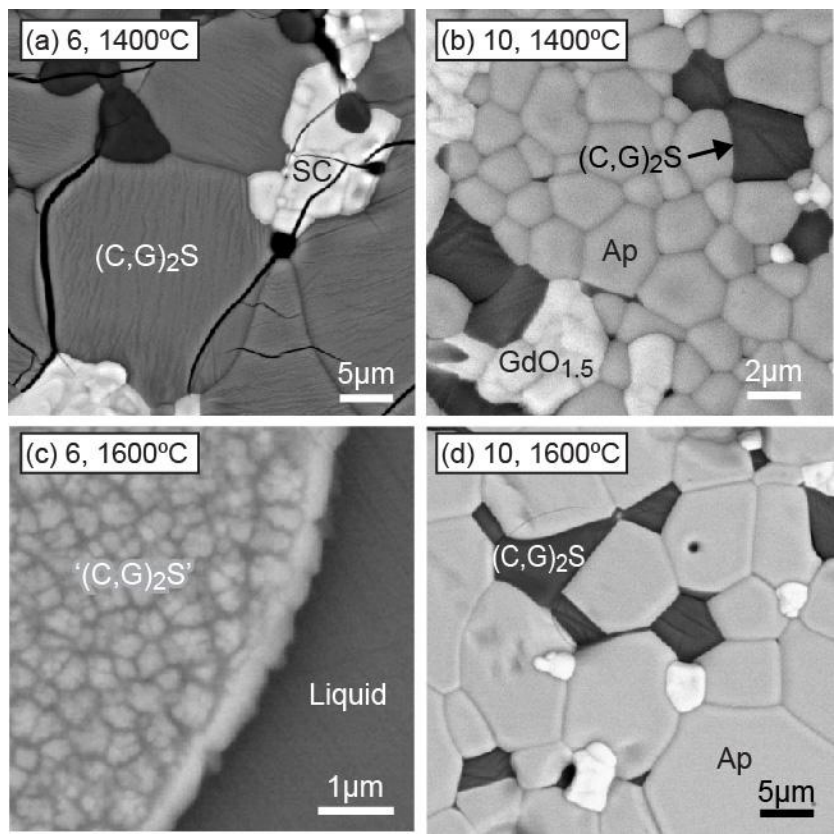

Figure 3: BSE micrographs showing the as-quenched microstructures of the $(\mathrm{Ca}, \mathrm{Gd})_{2} \mathrm{SiO}_{4}$ phase. The imaging conditions were selected so that each phase is clearly visible. As a result, the relative brightness of $(\mathrm{C}, \mathrm{G})_{2} \mathrm{~S}$ varies.

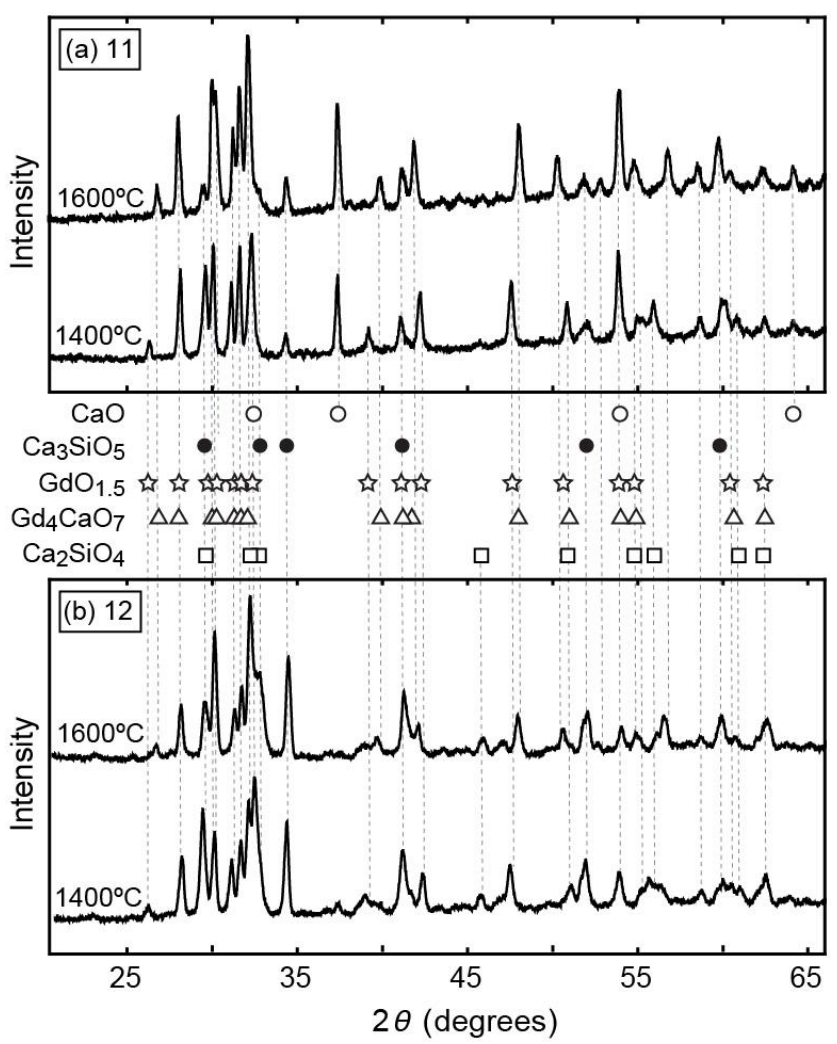

Figure 4: The XRD patterns for (a) ID 11 and (b) specimen ID 12 indicate that $\mathrm{CaGd}_{4} \mathrm{O}_{7}$ is stable at $1600^{\circ} \mathrm{C}$ but not $1400^{\circ} \mathrm{C}$. 

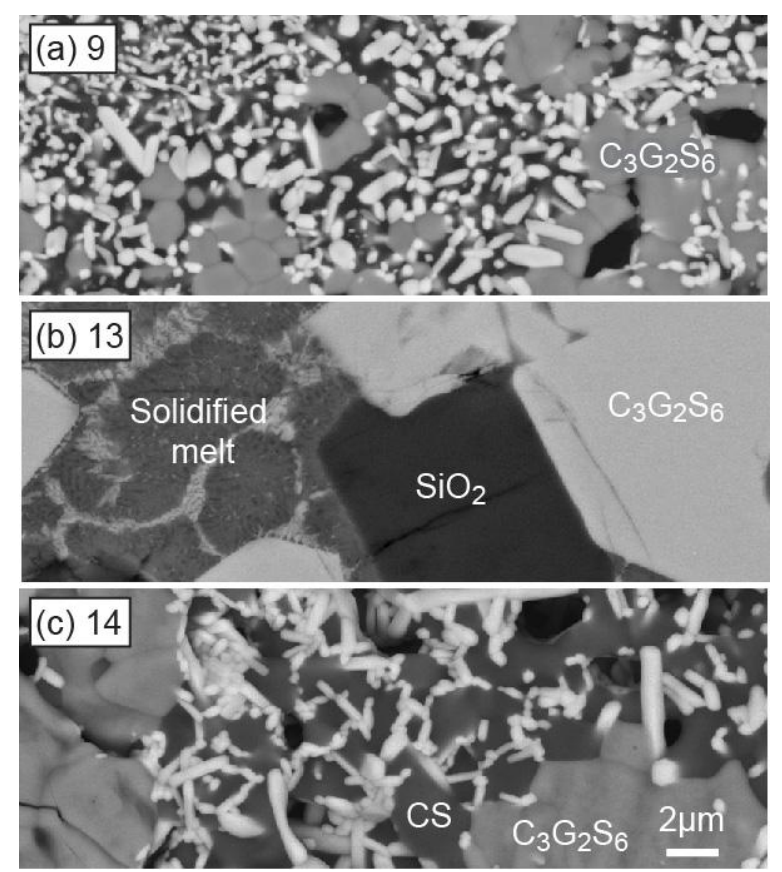

Figure 5: BSE micrographs showing the structure of the $1400^{\circ} \mathrm{C}$ specimens used to determine the stability and homogeneity range for the cyclosilicate $\left(\mathrm{C}_{3} \mathrm{G}_{2} \mathrm{~S}_{6}\right)$. The darkest phase in (a) is $\mathrm{SiO}_{2}$ and the bright phase in (a) and (c) is apatite.
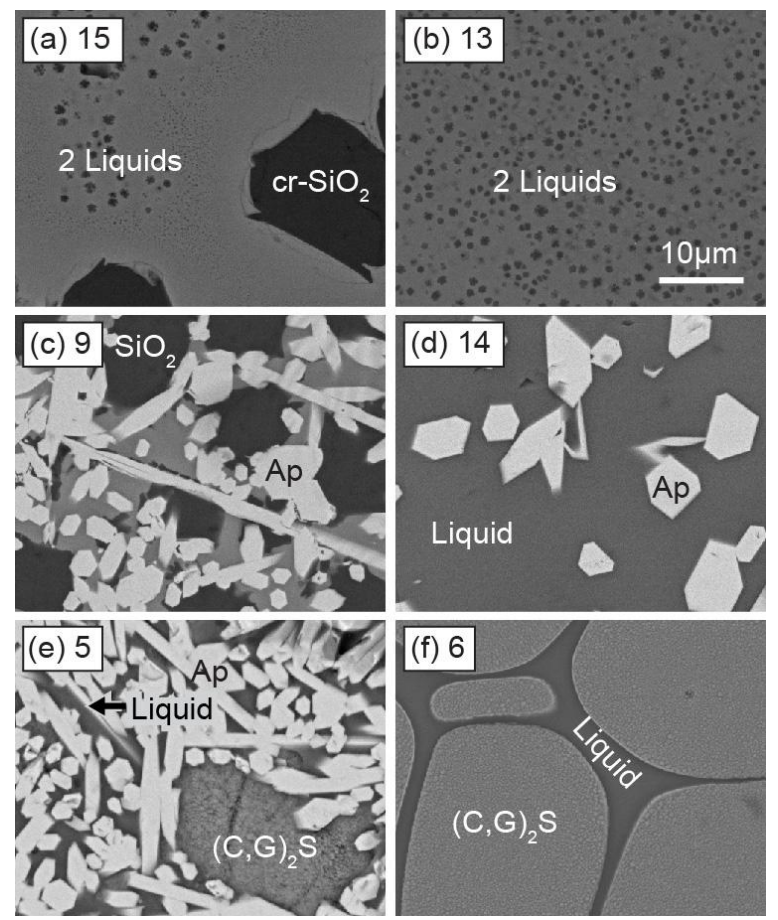

Figure 6: BSE micrographs of specimens containing liquid phase at $1600^{\circ} \mathrm{C}$. The magnification of all micrographs is equivalent. 
Graphical Abstract
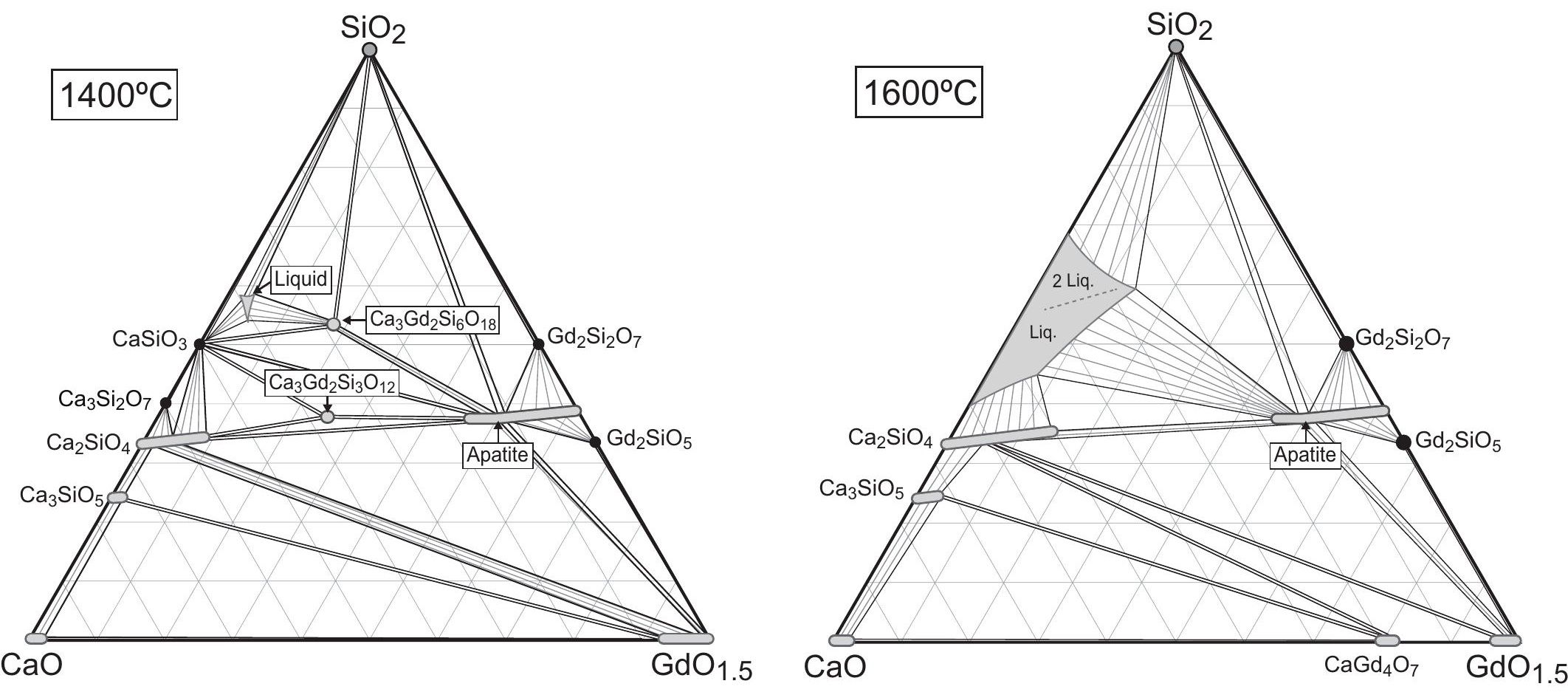